\title{
Land Grabbing and Smallholders in Ethiopia
}

\author{
Masresha Eskeziaw \\ Addis Ababa University, Department of Agricultural Economics
}

\begin{abstract}
Land grabbing is global issue affecting smallholder farmer's livelihood. With the objective of evaluating the impact of large scale agricultural Investments on the livelihoods of rural communities, this paper uses literatures on land grabbing supplemented by data from FAOstat and tries to identify the root causes of land grabbing and driving forces behind the agricultural investment in the country. It tries to assess the problems created due to introduction of large scale agricultural investment by foreign companies and its consequences on local communities. The remedial measures that should be used by the government to tackle the problems created due to high demand for agricultural land acquisitions were discussed for alternative policy option.
\end{abstract}

Keywords: Land grabbing, Agricultural investment, Smallholders

DOI: $10.7176 / \mathrm{JPID} / 56-02$

Publication date: November $30^{\text {th }} 2020$

\section{INTRODUCTION}

Ethiopia is one of the least developed countries with annual GDP accounted 72 billion USD (NBE, 2016). Agriculture contributes $45 \%$ of the GDP, $80 \%$ of the employment opportunity, $90 \%$ of the foreign exchange (MOA, 2013). According to MOA (2010) report, only about 11.7 million hectares of land (about $20 \%$ of arable area) and nearly 55 per cent of all smallholder farmers operate on one hectare or less.

Farm fragmentation has increasingly emerged as one of the key problems of subsistence farming in Ethiopia (Samuel, 2006) which makes the government a challenge to implement development strategies to farming community's at large scale. Average farm size of rural households is about one hectare and majority of rural households in food deficient area own extremely small farmland averages only 0.57 hectares compared to food surplus estimated 1.38 hectares (Diao et al, 2010). Irrigation covers only $3 \%$ of the cultivable land, however, investment in irrigation increase land productivity by at least $50 \%$, and when this is associated with soil fertility improvement, productivity can reach up to $300 \%$ (FAO, 2014a). Demand oriented projections of USDA show about 36 million people (35.2\% of the population) of Ethiopia are food insecure in 2016 (USDA, 2016). This indicates how much series the food insecurity status of the country is.

In Ethiopia $47 \%$ of children under five are stunted, $11 \%$ are wasted; $38 \%$ of children are underweight, $27 \%$ of women in reproductive age are chronically malnourished (FAO, 2014a). The greatest functional consequences of malnutrition for children besides illness and death are mental impairment and reduced capacity to produce and contribute to the economy. This problem seems sustained and make the future is uncertain or dark future for the country because the productivity of the coming generation is affected by what happened today.

In Ethiopia less than $5 \%$ of farmers have access to improved seed which aggravated by annual soil losses of about two tons per hectare, low level of fertilizer use and limited access to irrigation, impacts negatively on smallholder productivity in moisture and food deficient areas (FAO, 2014a).

Since 1994, Ethiopian government had formally adopted agricultural development led industrialization with the goal of attaining fast and broad based development within the agricultural sector and makes the sector development power broad economic growth (Diao et al., 2010). Agricultural Development Led Industrialization (ADLI) strategy in 1993, the Government initiated a two pronged approach to developing agriculture through the production of agricultural commodities for export, domestic consumption, and industrial output; and the expansion of the market for domestic manufacturers (ATA, 2016).

Fertility of soil and accessibility to the agricultural resources are determinants of Agricultural productivity in Ethiopia. Most farmers are involved in production activity with traditional way of farming and dependent on variable rainfall. The productivity and food security status of farm communities are directly dependent on this variable rainfall. When the rain fall is good, better agricultural production is gained hence food security status improves. As the situation became the reverse, the production affected and they suffer from food shortage for their families and their livestock.

Alternative production methods need to be implemented by smallholders to minimize the problem of production variability. Use of small scale irrigation scheme is a better solution for rainfall variability and allows smallholders to produce more than once in a year. However, it requires large investment cost unless covered by government or other donors. Government media's reported about the establishment of various community centred development schemes throughout the country including irrigation schemes that will benefit smallholder farmers. But the productivity problems and drought is still having media coverage in the lowland areas of the country. In some areas large scale irrigation schemes were established for huge agricultural investment projects 
that are owned by domestic and foreign investors. However, these large scale investment projects have their own objectives and these investments instead of improving the livelihood of smallholders; became a problem to farming communities and source of conflict, generally disturb their livelihood and even become a threat to their survival.

This paper tries to address the problems created due to introduction of large scale agricultural investment and other development projects on the livelihoods and food security status of smallholders' and what should be done to minimize deterioration of wellbeing of local communities hence the country. Hence, the objective of this review is to evaluate the concepts of land grabbing with the aim of large scale agricultural investments in Ethiopia. Specifically: to assess the impact of land grabbing on the livelihood and food security status of smallholders and to forward policy alternatives to minimize the impact of agricultural investment on smallholders

\section{REVIEW METHODOLOGY}

\subsection{Land Tenure system of Ethiopia}

The concept of 'tenure' is a social construct that defines the relationships between individuals and groups of individuals by which rights and obligations are defined with respect to control and use of land (ECA, 2004). The three notable tenure arrangements (Tesfaye, 2005) are: administrative-based, re-emerging market based, and customary-based non-market arrangements. The majority of farm households have land through administrative based allocation as peasant association land or Kebele land (Tesfaye, 2005).

The land tenure system of Ethiopia is considered as a major factor exacerbates diminishing farm size and environmental degradation (Anonymous, 2003). Even if the reality is by far different that what was stated, the federal constitution affirms the constitutionality of the state ownership of land and guaranteed free access to land, holders of land right are constitutionally protected from eviction (Tesfaye , 2005). The policy was the result of a centralized, top-down approach rather than being developed through consultations with all farmers, civil society, and businesses (Samuel, 2006).

\subsection{Land grabbing}

The concept of "land grabbing," is widely used to describe processes associated with expansion in transnational land acquisitions (Dell'Angelo et al, 2016). Land grabbing defined as the land loss by rural population due to large scale land acquisition by foreign business for agricultural production (Daniel, 1999). It is the result of a complex combination of factors motivated by price volatility in global markets, the global food crises, and high levels of speculative activity (Daniel, 1999). "Land grabs" is a term to describe large-scale purchases or leases of agricultural or forest land on terms that do not serve those already living on the land (Murphy, 2013). Land grabbing' or 'the farms race' in Africa has been described as a new neo-colonial push by foreign companies and governments to annex key natural resources (Hall, 2011). Daniel (1999) identified three main trends driving the land grab movement as: the rush to secure food supply, surging demand for biofuels, sharp rise in investment.

\subsection{Food security}

Food security is a concept in the discussions of international food problems at a time of global food crisis (FAO, $2014_{a}$ ). Its initial focus of attention was primarily on food supply problems - of assuring the availability and to some degree the price stability of basic foodstuffs at the international and national level (FAO, 2014a).

Food security is not only an essential component of human well-being, but also a foundation for political stability (Grebmer et al., 2015). Food security is assumed to be achieved when all people, at all times, have physical, social and economic access to sufficient, safe and nutritious food which meets their dietary needs and food preferences for an active and healthy life (FAO, 2013b). The definition of food security is considered to include four main components: availability, access, utilization, and stability (Díaz-Bonilla, 2015).

\subsection{Empirical review}

A study conducted by Baumgartner et al (2015) to analyze the impact of large scale agricultural investment on local livelihoods shows evidence of significant increase in Large Scale Land acquisitions in Ethiopia, especially after the global food price crises of 2007 and earlier federal policy changes. One of the simulation model results of the study shows, the establishment of LSAIs will change access to land, and thus have impacts on the income levels of the local communities as the commercial farm will occupy 10,000 ha that are thus lost to local users.

A study conducted by Maru and Rutten (2015) to investigate the impact of large scale agricultural investment on household incomes and food security, a survey of households who lost access to grazing and farm land as a result of a project, and the data was analyzed using the propensity scores matching technique and the result shows long standing competing claims to land resources and large scale farming reduces local communities food security status.

One of the questions raised by anti-land-grabbing activists is whether the exclusive mechanisms of a free 
market may be expected to work like magic with regard to ensuring the supply of food to all countries and populations of the world, without the involvement of national and local governments and authorities? (Constantina et al, 2017). Government actors are more in control of policy making both the opening up of private land ownership in the 1980's and to the land reform of 1990s and the role of donors were in financing activities with less decisive on the reform design (Pedersen, 2016). Experts agree that population growth, rising incomes, and urbanization will continue to drive demand growth for some food, especially vegetable oils and livestock, with higher derived demand for feed and for industrial products (World Bank, 2011).

A study shows in Europe, land grabbing occurs mostly in the Eastern and Central countries, particularly in Hungary and Romania, because they possess some of the best agricultural lands, with extremely fertile soil and water sources for irrigation in the Danube plain and the imbalance and inequality between the power and size of the national and international capital has widened the gap (Constantina et al, 2017). The liberalization of markets and trade in 1980s, land abundant countries in Latin America capitalized on growing global demand to increase their position in world markets. Higher prices, improved technology, and lower transport costs pushed out the land frontier. Hence increase production and export the outputs (World Bank, 2011). Study conducted by FAO (2014b) shows land acquisitions in Mali and Senegal are based on accessibility criterion for choice of target area: the majority of deals may be less than three hours away from the next city and the lands targeted by investors are located near roads and markets. According to the FAO report national indicators of these countries suggest large reserves of suitable land, transactions are found within cultivated areas and farmland which questions the assumption that investments are mostly focused on non-utilized land to serve in bringing into production. A study conducted in western part of the country show that agricultural investment in Ethiopia has negative impact on the livelihood of smallholders. The adverse effects of foreign direct investment (FDI) particularly large scale land acquisitions are; it raise complex economic, social, political and environmental issues (FAO, 2014b). The exact terms of land deals in Africa usually happen without knowledge of landholders (Cotula, 2011). International donors headed by the World Bank are criticized for imposing 'neoliberal' land reforms that ignore the local land rights in Africa (Pedersen, 2016).

\section{RESULTS AND DISCUSSION}

\subsection{Agricultural Investment in Ethiopia}

It is assumed after several decades of under investment in the agricultural sector in developing countries, the late 2000s witnessed a surge in foreign direct investment (FDI) in primary agricultural production (FAO, 2013b). In Ethiopia foreign direct investment (FDI) to the agricultural sector account for $32 \%$ of the total inflows (Weissleder, 2009). The Agriculture Sector Policy and Investment Framework (PIF 2010 - 2020) provides a strategic framework for the prioritization and planning of investment that will serve as an engine for driving Ethiopia's agricultural development (FAO, 2014b). It is designed to operationalize the CAADP Compact signed by the Government of Ethiopia and its development partners in line with the GTP. The CAADP Compact and PIF are critical in terms of policy alignment and securing the finance needed for sector development both from domestic and international sources (FAO, 2014b). One of the main short term benefits of FDI is job creation, but the new jobs may not sustainable and some projects are labour intensive initially and mechanized gradually (FAO, 2013b). The new jobs may require special skill that is not known by the host country's labour. As a result laborers may come from outside which erodes the employment opportunity of the citizens. That is true when opponents of FDI arguing on the behalf of citizens right. The jobs that have been created pay a wage below the World Bank's poverty limit (Vhughen and Aman, 2009). Wage rates for agricultural labor are low, typically between USD 0.60 and USD 1.20 (10-20 birr/day) (OI, 2011b).

Some evidences show how foreign firms are harming the country's benefits that foreign firms are not fulfilling their commitment in the land deal. As an example Indian land investments least benefit the country. Interestingly, the expected yields of the company are far below the existing average yields in Ethiopia (Hulesa and Singh, 2016). As evidence Ethiopian government takes measures against the Indian company due to failure in fulfilling the commitment.

In Ethiopia smallholders cultivate $94 \%$ of total cultivated land in 2013/14 (Bachewe et al, 2015). Only 400,000 ha accounting for large-scale commercial farming (Hulesa and Singh, 2016). From a total of 73 million ha of arable land, 15 million has is under cultivation and earmarked 700,000 ha of land for sugar cane, 23 million ha suitable for Jatropha. The identified foreign companies involved in biofuel production according to Hulesa and Singh (2016) include: UK-based Sun Biofuels operates 5,000 ha; Acazis AG (German) leases 56,000 ha with concessions for another 200,000 ha (Africa: up for grabs, 2010). The largest land acquisitions were made by the Indian company, Karuturi Agro Products Plc (111,700 ha) and the Saudi company, Saudi Star (100,000 ha) in Gambella region. Karuturi acquired 11,700 ha land in Oromia and100,000 ha in Gambella, with the possibility to extend to 300,000 ha in Gambella. The average land investment size by Indian firms is around 17,000 ha, excluding the 100,000 ha land deal from Karuturiin Gambella (Hulesa and Singh, 2016).

The major reasons for the increasing large scale agricultural land investments identified as: boom for bio- 
fuel policies across the world; rising food prices (crisis) in the world market; and the global financial crisis of $2007 / 2008$ that caused investors to seek alternative sources of investment with a view to reducing the effects of financial market volatility (Osabuohien, 2014).

Figure 1: Foreign Direct investment from 1990 to 2015

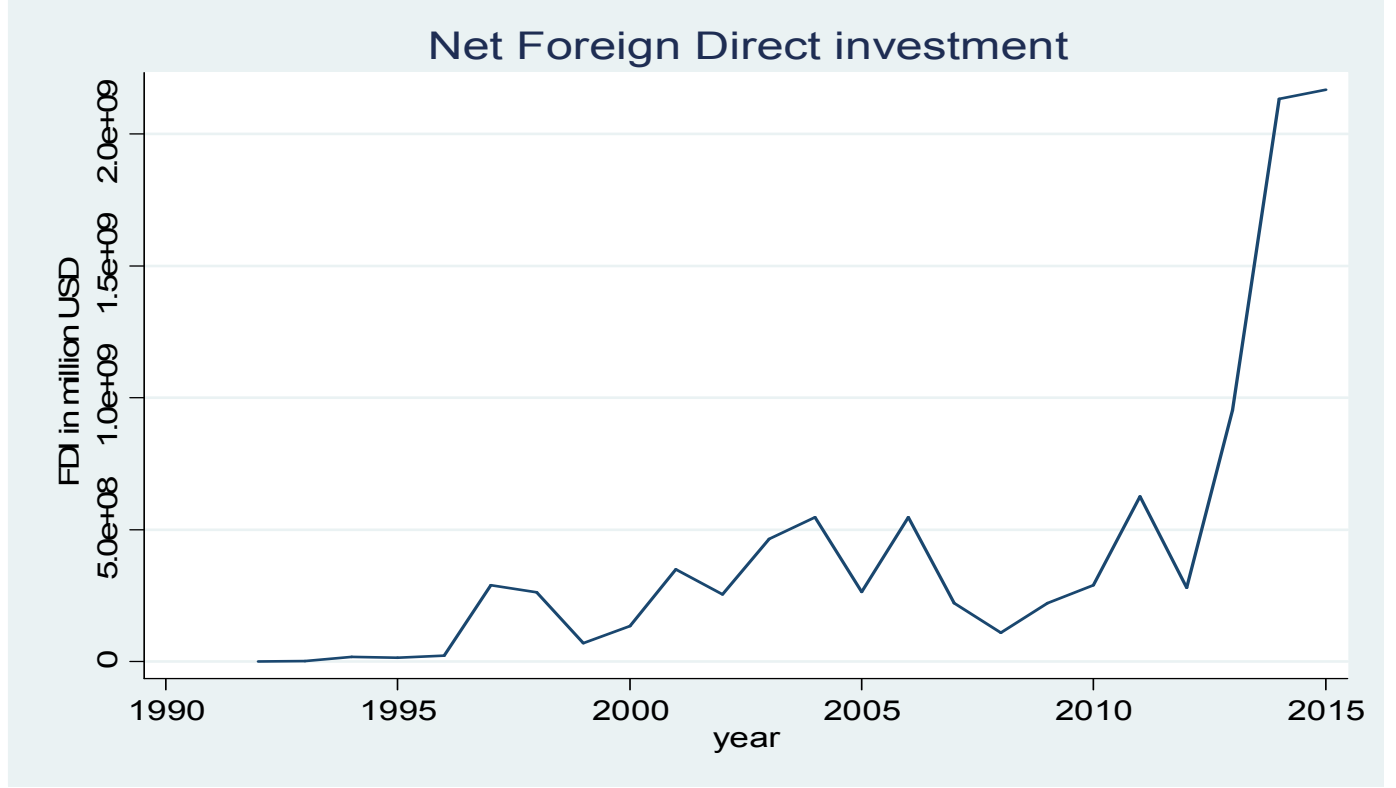

Source: FAOstat accessed on 2/7/2017

Fig 1 above shows foreign direct investment flow in Ethiopia. The figure indicates drastic rise of FDI after year 2010 onwards and shoots up. The graph clearly shows the stagnant or no FDI flow to Ethiopia in 1990's. The FDI flow includes $32 \%$ of its share is for agriculture and clearly shows how agricultural investment increases at the same time the amount of land for agricultural investment increases from time to time.

Figure 2 below shows the development assistance to agriculture and this is also shows drastic rise after year 2005 and reaches its climax around 2010 and it gradually it declines 2010 onwards.

Figure 2: Development assistance to Agriculture from 1990 to 2015

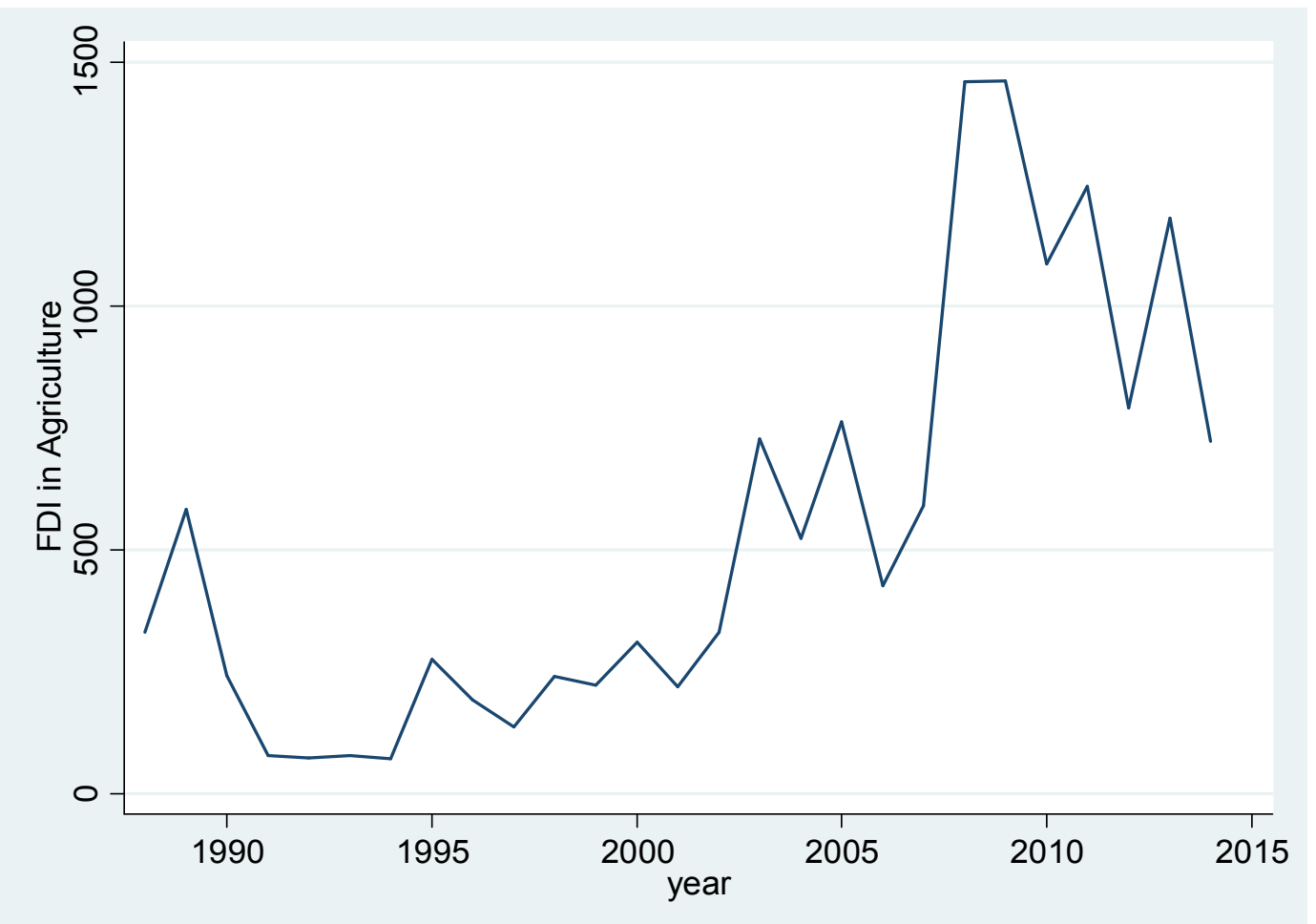

Source: FAOstat accessed on 2/7/2017 


\subsection{Derivers and Policies of Land Grabbing}

Based on literatures, three major deriving forces for land grab in Ethiopia identified as: international market situation, regional and international incentives and financial resource flow. The international market situation which raises demand for food, biofuel and increase in prices is one factor, the regional and international incentives to encourage agricultural investment in the domestic soil and the financial resource flow from foreign country to domestic economy. These factors are the major forces that encourage modifying the investment policies of the country.

\subsubsection{International market situation}

Boom for bio-fuel policies, rising food prices, and global financial crises of 2007/08 are major reasons for increase in land acquisitions (Osabuohien, 2014).The acquisition of land by private and government entities in hope of profit, securing food supply, acquiring energy and manufacturing resources and generating profits from private investments is the strategies of acquiring foreign land (Daniel, 1999). Concerns about energy supply appear to be a key driver behind the demand for agro-fuel crops with the EU aiming for $10 \%$ of transport fuel to come from "renewable" sources by 2010. These EU targets have established a clear market - which given land prices and the lack of available land within the EU will inevitably be met by imports (Africa: up for grabs, 2010). Some of the drivers behind land grabs predate the global food price crisis, such as the rise of the biofuel industry from approximately 2004 (Murphy, 2013). This leads foreign governments seek food security for their people to avoid political instability of the country too. Volatile food prices demanded for greater food security through acquisition of land beyond borders (HLPE, 2011).

\subsubsection{Regional and international policy incentives}

Availability of cheap land coupled with weak land governance encourages the purchase or lease of land by individuals and entities in Africa (Osabuohien, 2014). European development cooperation is actively supporting the introduction of agro-fuel policies in African countries (Graham et al., 2011). The African union's comprehensive agricultural development program (CAADP) committed member state governments to invest $10 \%$ of government expenditure in agricultural sector (HLPE, 2011). Followed by CAADP commitment, the Ethiopian Government has leased at least one million hectares (ha) of land for agricultural investments over the period 01 January 2005 to 31 August 2012 (Keeley et al, 2014).

International private sector investment is attracted due to increase in prices of food and food production, biofuel production, finance sector provide credit for agriculture, and ecological drivers of international investment in land. These environmental drivers include: gaining access to water; drought and degradation; biofuel policy; conservation of biodiversity; and other carbon sequestration schemes (HLPE, 2011).

Investors in all sectors of the Ethiopian economy including foreign investors who will be engaged in agricultural activity are exempted from the payment of custom duties and other taxes levied on imports of all capital goods necessary for the establishment of new projects or expansion/upgrading of the existing one (Weissleder, 2009).

\subsubsection{Financial resource}

Due to capital scarce for most Agrarian nations, one of the solutions of shortage of capital is attracting foreign investors by amending their investment laws. The World Bank and international finance corporation support reforms in the business climate, hence countries set investment promotion agencies to secure investment and revise investment codes of the country (HLPE, 2011). The International Finance Corporation (IFC) promotes economic growth in the developing world by financing private sector investments and providing advice to governments and businesses (Daniel, 1999). Low investment in the agricultural sector resulted in low productivity and stagnant in production, and it is believed that agricultural investments can reduce the vulnerability of food supplies shocks, stability in consumption (FAO, 2014b).

\subsection{Problems of Land Grabbing}

Large scale agricultural land acquisition is the major problem that harms the rural community in displacing from their ancestral land, eliminating the food security status of smallholders and a cause for environmental degradation. Once farmers/ pastoralists have dislocated from their land, they all lose their livestock and livestock products, subsistence agricultural crop production where they have experienced earlier. The loss of land, whether farmland, communal areas, grazing areas, or areas of religious or cultural value, has serious adverse impacts on local people, their food security, their identity and the socioeconomic conditions (OI, 2011a). In the recent period it is remarked an increased attention of the foreign citizen, companies and other actors in buying land. The sale and long rental of agricultural land has attracted massive social, political and numerous local communities argues infield (Constantina et al, 2017). Land grab bring Agricultural investment to poor countries but at the expense of smallholders (Daniel, 1999). That is why as purchase and lease of large tracts of arable land have allegedly provided the problems behind protests, riots, coups, and other conflict (Thaler, 2013). The negative impacts of large scale agricultural land acquisitions in dislocating indigenous communities, problems in food insecurity, environmental degradation are under discussion. 


\subsubsection{Dislocation of residents}

Land rights and relocation of farmers remain a big challenge in Ethiopia. The expansion in production areas required households to be relocated, the majority of whom have been living in public lands for many years. In sugar project areas of Ethiopia, these farmers would become landless facing the choice of either staying in the area as sugar workers or moving away, but in either case they will receive a certain amount of compensation to their purported losses (FAO, 2013a). An impact assessment carried on the impact of Gilgel Gibe project owned by Ethiopian Electric Corporation will affect a total of 355 households, about 188.94 hectares of privately owned land of which 138.7 ha is farm land (EEPCO, 2009). However the Oakland Institute (2011) study shows the dam would have devastating effects on the 200,000 agro pastoralists of the lower Omo valley and 300,000 people whose livelihood depend on lake Turkana. In both studies at least it is clear that significant numbers of community members are dislocated due to this large project.

Large scale agricultural investment will create employment for subsistence farmers at the expense of forcing them off their land (Daniel, 1999). The government defend the ideology of state control of land entitlement of free land to all to ensure subsistence, and a great fear that opening land markets would provide inroads for involuntary dispossession of land from poor and vulnerable peasants, however, the reality in the ground shows some of the policy inconsistencies and contradictions in pursuing the goals of equity, efficiency and sustainability are inherent in these guiding political principles (Tesfaye, 2005).

The government's claim is that state-ownership of land helps protect peasants against market forces but it is believed that the government uses land as apolitical weapon and has the power to decide to give to or take land from landholders (Hulesa and Singh. 2016). The community development program (CDP) has resulted in forced eviction of local communities and the seizure of land and water resources on which millions of Ethiopians rely for their livelihoods (OI, 2016).

The study conducted by the Oakland institute ${ }^{a}$ (2011) indicates, the issue of land in Ethiopia is not merely a commodity but is a critical component of their identity and the loss, whether farmland, communal areas, grazing areas, or areas of religious or cultural value, has serious adverse impacts on local people, their food security, their identity and their socioeconomic conditions. Ethiopia's large scale agricultural investments for export crops such as sugar, cotton and large dams for electricity and irrigation schemes involve forced evictions of local communities and the seizure of land and water resources on which local communities rely for their livelihoods (OI, 2016). This forced displacing of farming communities from their land which is under customary tenure lead to outbreak of social conflicts (Ravagnani, n.d).

The main actors affected by land acquisition as assessed by World Bank group were primarily smallholders (Dell'Angelo et al, 2016). The assessment result indicates, $61 \%$ of the acquired land was designated for large scale production of food crops and $36 \%$ for non-food including biofuel production.

Large tracts of land are acquired by international companies for producing crops for export (Hulesa and Singh, 2016). India's acquisitions in Ethiopia qualify as land grabbing. Employment generation, technology transfer, and infrastructure development were the commitments of Karaturi but failed to fulfill.

Since 2008 over 350,000 hectares of land has been earmarked for commercial agricultural production in the Lower Omo Valley (OI, 2011a). Large hectares of land are given for foreign investors of which Indian and Saudi companies have leased 100,000 and 140,000 hectares of land in 2012 (Grain, 2012).

Land acquisition has evolved over time with variations across regions and commodities in the balance between area expansion and intensification, the role of large-scale and small-scale farming, and the resulting social and environmental impacts (World Bank, 2011). The main purposes of land acquisitions (food or biofuel); and the extent to which the availability of land and water resources can be considered as a driver of land acquisitions (Antonelli et al, 2015).

The history of land grabbing goes back from pre-colonial inter-tribal conflicts for land possession, and the trend of lying hands on territories of gaining control over landed properties and over the soil and sub soil riches associated therewith has acquired new dimensions and has found new modes of operation (Constantina et al, 2017).

\subsubsection{Food security}

In Ethiopia the food security of smallholders is threatened by land degradation and droughts that cause declining and highly variable land productivity (Holden $e t a l, n . d)$. The policy directives of EU have diverted the resources to biofuel production; investors require large area of investment land for production of energy crops. This intern diverts food production to energy which raises food prices hence food insecurity.

The areas of intensive land investment became a cause for food insecurity. It is because of their resource ownership with ample water supplies and good soil fertility demanded by investors. Smallholders in the prime land investment areas with fertile river valleys in western and southwestern parts of the country and some in Afar region, they face food security problems (OI, 2011a).

Since the products produced by foreign investors be exported to the other African and international markets to obtain more value for the outputs (Hulesa and Singh, 2016), it affects the food security of the country. In 
addition these foreign investors have prior agreement with their nation to export (bring back) part of their outputs. Saudi and Indian companies have such type of commitment (Hulesa and Singh, 2016).

Land deals eliminate the food security status for poor nations by transferring resources to foreigners (Daniel, 1999). Most countries are net food importers even emergency food aid recipients including Ethiopia. An evidence of the negative impact of land deals on food security was observed in Bachewe et al (2015) that agricultural output doubled by area expansion and yield, however, the change does not reduce food shortage instead it increases. The number of aid recipients every year increases. Since 2005 the number of food recipients for their survival increase from 8 to 18 million (OI, 2016). It is ironical that the Ethiopian government encourages food production for export rather than for domestic markets (OI, 2011a). The largest donors, the United States, the United Kingdom, and the World Bank, have been closely involved in the design of its development strategy and play a key role within a number of aid mechanisms established to deliver it (OI, 2016).

There has been rise in FDI into agri-food sector of developing countries since 2007/08 and the share goes to this sector doubled between the periods 200-2005 and 2006-2008 (FAO, 2014b).

Better productivity, rise in food availability, job creation, poverty reduction, technology transfer and access to capital and markets are some benefits generated from Agricultural investments, however, these benefits depend on investment contract, type of business model, linkages with smallholders and the institutional framework in the host country (FAO, 2014b).

Villagization and displacement of people, loss of farm land, degradation and destruction of natural resources, and the reduction of water supplies are expected to result the loss of livelihoods and these households were largely self sufficient in food production and now rely on assistance from others and will become more dependent on government. Change in diet, loss of traditional lands, increased reliance on wage employment and aid, and weakened community bonds will also result from this livelihood loss (OI, 2011b).

A study conducted in Ethiopia to determine the degree of food insecurity that was the results of land transfer to Karuturi indicate that the affected households on average lost $20-27 \%$ of their consumption expenditure compared to the non-affected households (Maru and Rutten, 2015). This was one of the problems due to lack of concern to the livelihoods of smallholders. According to Daniel (1999), factors that affect food security including the 2008 food price crises and consequent increase in import bills, inflation rates, harsh climatic conditions, scarce land and water combined with economic and demographic growth have led many nations to reexamine domestic security policies. According to Global hunger index Ethiopia ranked 93 with 33.9 in 2015 (Grebmer et al, 2015). As indicated in Fig.3 below, the situation of food aid in different time periods in Ethiopia. It is understandable that the food aid rises from time to time.

Figure 3: Food Aid delivered for Ethiopia from 1990 to 2015

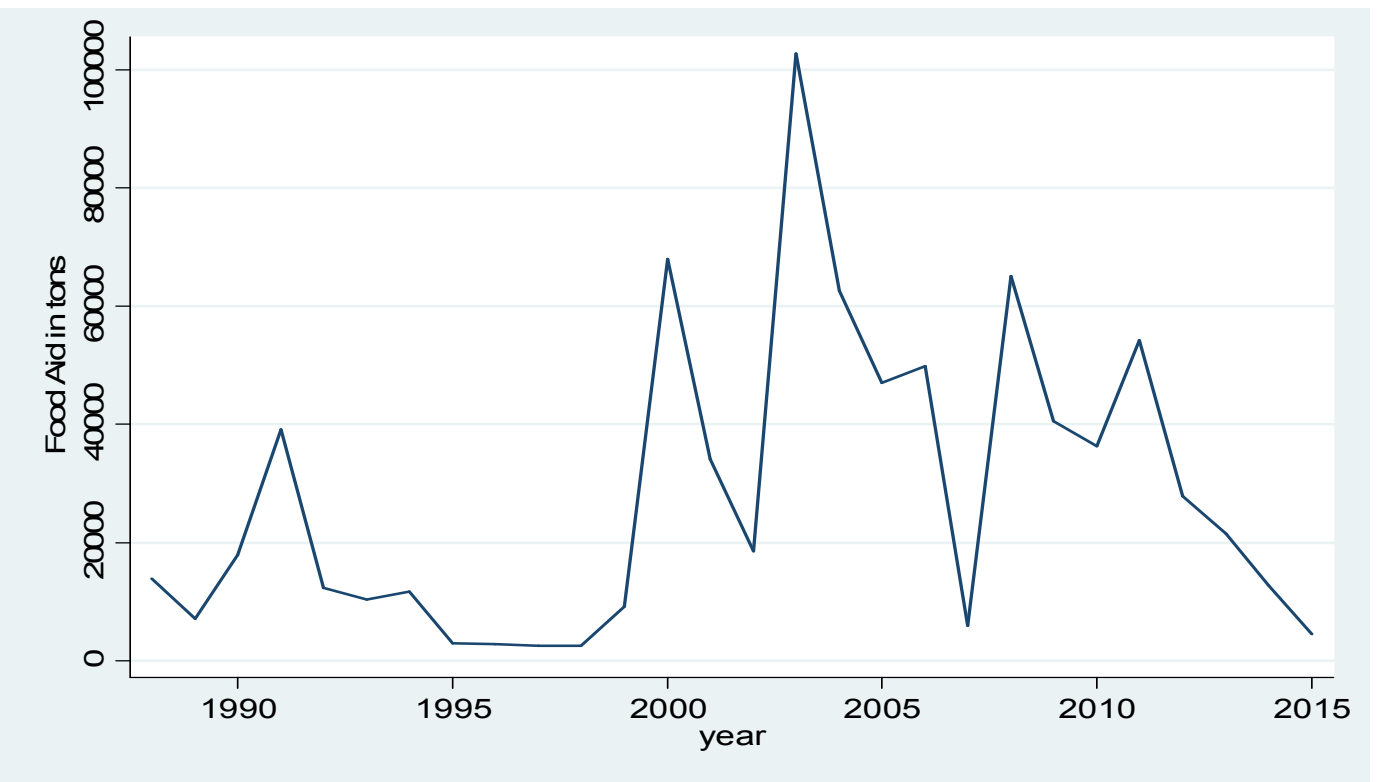

Source: FAOstat accessed on 2/7/2017

\subsubsection{Environmental degradation}

Even if the Ethiopian government assumes zero environmental impact on large dams, environmental activists have raised concern about environmental degradation, disturbance of the biodiversity, and threat to Lake Turkana due to Gilgel Gibe III project (EEPCO, 2009). In almost all of the investment sites visited by OI, leased out forest areas were cleared by bulldozer, domestic investors were also felling trees to sell firewood locally (OI, 2011a). Forest clearing disturbs the natural environment and biodiversity of the area which will create an 
ecological imbalance in the area.

According to OI report, larger scale investors (usually foreign) seem to clear with larger machinery and then burn the cleared wood and debris. Other potentially significant adverse environmental impacts include loss/degradation of wetlands, decrease in quantity/quality of wildlife populations and habitat, impacts to water quality/quantity, the proliferation of invasive species, and loss of biodiversity. There is virtually no transparency regarding land investment negotiations and agreements (OI, 2011a).

\section{Conclusion and Recommendation}

Agricultural investment is the very important development activity that brings the agricultural production to raise and fulfil the sustainable supply of agricultural output to feed the citizens of the country. A country with a population of $85 \%$ dwells in agricultural activity but dependent on foreign food aid to feed the population and 8 to 18 million of people suffer in starvation. To bring the economy to the right track, Ethiopian government introduces agricultural development strategies in earlier periods. But the strategies are not successful as promised and reported. It is has coverage by the government Medias that the number of people requiring food aid increasing from time to time.

As part of agricultural led industrialization strategy, Ethiopian government encourages large scale agricultural investment in the country with the objective of increasing domestic production but for export. This strategy attracts foreigner to invest in the country but with the objective of producing to export to their native nation. This investment strategy creates a great challenge to the rural communities. The reason is the agricultural investment instead of improving the livelihood of smallholders, it aggravates the situation. The livelihood situation declined from time to time, smallholders are losing their ancestral lands in the name of agricultural investment by foreign and domestic investors. As it was discussed, large hectares of land are given for foreign investors for agricultural production and biofuel production. Smallholders do not have ownership right on their land, and the product produced is designed for foreign market. Whatever output is produced the products are exported to investors' home country based on the agreement between the investor and the origin of investor's country.

Ethiopian government has eliminated the ownership right of smallholders on their land. This allows transferring large hectares of land to foreign investors without consent with local communities. Based on ownership right of the government on agricultural land, relocate indigenous communities residing around the investment areas. Relocating of indigenous people without their consent have negative impact on the sociocultural interaction of the communities and the situation leads to social disturbance, if the disagreement aggravated it incurs a cost on the investment activity, create social and political unrest in the area. There were some indications of destruction and social unrest in western and southwestern parts of the country due to the loss of their land (OI, 2016). It is clear that improving agricultural productivity brings the economy in the right track but with the appropriate policy and development strategy with the consent of communities which incurs minimum impact on the rural poor.

Agricultural investment is a base for countries with agricultural led industrialization policy. Agricultural sector need to be boosted if technological advancement is added to the existing production activity. Mechanized farms may be important for increased production by utilization of agricultural inputs efficiently. The problem is how to implement mechanized farm in a country with a protracted smallholder farm. Without violating the land tenure policy of the country the dream will be achieved if there is a thorough discussion with stakeholders.

As a remedy it is recommend that:

1. The government has to encourage smallholders to have irrigation access at smallholder level that allows producing more than once in a year to increase agricultural production.

2. Land owners and community leaders should take part in decision making to their ancestral land, thorough discussion and consensus should be reached between the government and the local communities about the agricultural development project that will be implemented and convinced about the benefits gained from the project. This will reduce riots, destruction on human and natural resources, forced eviction.

3. Priority need to be given for investors of agricultural sector for increasing agricultural production with the objectives in fulfilling domestic food requirement. Delineate the land for agricultural production, floriculture or biofuel production to avoid competition with food crops production.

\section{REFERENCES}

Africa: up for grabs. 2010. The scale and impact of land grabbing for agrofuels. Report friends of the earth Africa and friends of the earth Europe. www.foeeurope.org.

Agricultural Transformation Agency (ATA). 2016. Transforming Agriculture in Ethiopia. Annual report.

Anonymous. 2003. Ethiopian Agriculture: Macro and Micro Perspective for Afrint Macro Study. July 2003 Addis Ababa. 
Baumgartner P., Braun J. V., Degnet Abebaw and Muller M. 2015. Impacts of Large-Scale Land Investments on Income, Prices, and Employment: Empirical Analyses in Ethiopia.

Constantina C., Chivu Luminit, and Andrei J. V. 2017. Land grabbing: A review of extent and possible consequences in Romania. Land Use Policy 62:143-150

Cotula, L. 2011. Land Deals in Africa: What is in the Contracts? IIED, London

Diao Xinshen, Alemayehu S, Bingxin Y., Alejandro N. 2010. Economic Importance of Agriculture for Sustainable Development and Poverty Reduction: The Case Study of Ethiopia. Global Forum on Agriculture 29-30 November 2010. Policies for Agricultural Development, Poverty Reduction and Food Security OECD Headquarters, Paris.

Díaz-Bonilla E. 2015. Macroeconomics, Agriculture, and Food Security. A Guide to Policy Analysis in Developing Countries.

Economic commission for Africa (ECA). 2004. Land Tenure Systems and their Impacts on Food Security and Sustainable Development in Africa. Economic commission for Africa. http://www.uneca.org.

Ethiopian Electric Power Corporation (EEPCo). 2009. Environmental and social impact assessment. Gibe III Environmental and Social Impact Assessment.

Fantu N. Bachewe, Guush B., Bart M., Alemayehu S. Taffesse. 2015. Agricultural Growth in Ethiopia (20042014): Evidence and Drivers. Ethiopia Strategy Support Program (ESSP) of IFPRI and the Ethiopian Development Research Institute (EDRI). Working paper 81. October 2015.

Food and Agriculture organization (FAO). 2014b. Impacts of foreign agricultural investment on developing countries: evidence from case studies. FAO commodity and trade policy research working paper no. 47

Food and Agriculture organization (FAO). 2014a. Food and agriculture organization Ethiopia country programming framework. Revised document, September 2014.

Food and Agriculture organization (FAO). 2013a. Structural Changes in the Sugar Market and Implications for Sugarcane Smallholders in Developing Countries: Country Case Studies for Ethiopia and the United Republic of Tanzania. FAO Commodity and Trade Policy Research Working Paper No. 37.

Food and Agriculture organization (FAO). 2013b. Trends and impacts of foreign investment in developing country agriculture: Evidence from case studies.

Food and Agriculture organization (FAO). 2008. Food Security Information for Action Practical Guides. www.foodsec.org/docs/concepts guide.pdf.

Food and Agriculture organization (FAO). 2003. Trade Reforms and Food Security: Conceptualizing the Linkages.

Graham A., Aubry S., Künnemann R. and Suárez S. M. FIAN. 2011. The Role of the EU in Land Grabbing in Africa - CSO Monitoring 2009-2010.

GRAIN. 2012. Land grab deals / Jan 2012. www.grain.org.

Grebmer K. von, J. Bernstein, A. de Waal, N. Prasai, S. Yin, and Y. Yohannes. 2015. Global Hunger Index: Armed Conflict and the Challenge of Hunger. Bonn, Washington, DC, and Dublin: Welthungerhilfe, International Food Policy Research Institute, and Concern Worldwide.

HLPE. 2011. Land tenure and international investments in agriculture. A report by the High Level Panel of Experts on Food Security and Nutrition of the Committee on World Food Security, Rome 2011.

Holden S., Bekele Shiferaw, and John Pender. ND. Policies for Poverty Reduction, Sustainable Land Management, and Food Security: A Bioeconomic Model with Market Imperfections.

Hulesa M., Singh S. Jit. 2016. India's land grab deals in Ethiopia: Food security or global politics? Land Use Policy 60: 343-351.

Keeley J., Wondwosen Michago Seide, Abdurehman Eid and Admasu Lokaley Kidewa. 2014. Large-scale land deals in Ethiopia: Scale, trends, features and outcomes to date London: IDRC and IIED.

Maru Shete and Rutten M. 2015. Impacts of large-scale farming on local Communities' food security and income levels: Empirical evidence from Oromia Region, Ethiopia. J. Land Use Policy 47: 282-292.

Ministry of Agriculture (MOA). 2013. Agricultural investment opportunities in Ethiopia. www.moa.gov.et.

Ministry of Agriculture (MOA). 2010. Ethiopia's Agricultural Sector Policy and Investment Framework (PIF) 2010-2020. Draft Final Report 15 September 2010.

Osabuohien C. Evans S. 2014. Large-scale agricultural land investments and local institutions in Africa: The Nigerian. Land Use Policy 39: 155-165.

Ravagnani R, M. ND. Background review on social impacts of land grabbing associated to biofuels production. Brazil.

Ruth Hall. 2011. Land grabbing in Southern Africa: the many faces of the investor rush, Review of African Political Economy, 38:128, 193-214

Pedersen R. H. 2016. Access to land reconsidered: The land grab, polycentric governance and Tanzania's new wave land reform. Geoforum 72: 104-113.

Samuel Gebreselassie. 2006. Land, Land Policy and Smallholder Agriculture in Ethiopia: Options and Scenarios. 
Future Agricultures Discussion Paper 008, March 2006.

Shepard Daniel. 1999. Land Grabbing and Potential Implications for World Food Security. FAO, 1999.

Sophia Murphy. 2013. Land Grabs and Fragile Food Systems. The Role of Globalization. Institute for Agriculture and Trade Policy, February 2013.

Tesfaye Teklu. 2005. "Land Scarcity, Tenure Change and Public Policy in the African Case of Ethiopia: Evidence on Efficacy and Unmet Demands for Land Rights". International Conference on African Development Archives. Paper 89.

Thaler K. 2013. Large-Scale Land Acquisitions and Social Conflict in Africa. International Conference Yale University September 14-15, 2013. The Journal of Peasant Studies.

The Oakland institute, 2016. Miracle or Mirage? Manufacturing Hunger and Poverty in Ethiopia.

The Oakland institute (OI). 2011a. Understanding Land Investment Deals in Africa Country Report: Ethiopia

The Oakland institute (OI). 2011b. Land Deal Brief |September 2011. Understanding Land Investment Deals in Africa: Half a Million Lives Threatened by Land Development for Sugar Plantations in Ethiopia's Lower Omo Valley. www.oaklandinstitute.org.

United States Department of Agriculture (USDA). 2016. International Food Security Assessment, 2016-2026, GFA-27 Economic Research Service/USDA.

Vhughen D. and Aman Gebru. 2013. Large-Scale acquisitions of Land in Ethiopia.

Weissleder Lucie. 2009. "Foreign Direct Investment in the Agricultural Sector in Ethiopia," University of Bonn, October 2009.

World Bank. 2011. Rising Global Interest in Farmland. Can it yield sustainable and equitable benefits? The International Bank for Reconstruction and Development. The World Bank. 